\title{
IMPACT OF MARIJAMPOLE் WASTEWATER TREATMENT PLANT ON WATER QUALITY OF THE ŠEŠUPE RIVER
}

Laima ČESONIENĖ, Institute of Environment and Ecology, Agriculture Academy, Vytautas Magnus University, K. Donelaicio str. 58,44248 Kaunas, Lithuania, laima.cesoniene@vdu.lt

Midona DAPKIENĖ, Institute of Hydraulic Engineering, Agriculture Academy, Vytautas Magnus University, K. Donelaicio str. 58, 44248 Kaunas, Lithuania, midona.dapkiene@vdu.lt (corresponding author)

Tauras VASILIAUSKAS, JSC “Sūduvos vandenys“, Aušros str. 17, LT-69478 Marijampolè, vasiliauskas.tauras@gmail.com

\begin{abstract}
The aim of the paper was to determine the impact of Marijampole city wastewater treatment plant (WWTP) on the water quality of the Ššupe River. The wastewater and surface water samples were collected from January 2015 until January 2018. The condition of the surface water the Šešupe River condition is assessed 100 meters before the release point and 500 meters after the release point. The results show that the wastewater treatment is treated efficiently. It has been determined that the values all indicators of wastewater treatment efficiency duration of the study was the same (the function was negative, and the determination coefficients were very low: $\mathrm{R}^{2}=0.03 ; \mathrm{R}^{2}=0.012 ; \mathrm{R}^{2}=0.0006$ and $\left.\mathrm{R}^{2}=0.034\right)$. The treated wastewater is released from the Marijampole WWTP into the Ššupe River. The highest concentration according to all examined indicators was in 500 meters after the release of the wastewater. All differences were found to be statistically significant. It shows that, although wastewater is efficiently treated, it has a negative impact on the water quality of the Šešupe River.
\end{abstract}

Keywords: chemical quality indicators, efficiency, wastewater treatment plant.

\section{INTRODUCTION}

Contaminated river water is a growing problem not only in Lithuania, but also in the whole world. This is directly related to ecosystem degradation and human health. Knowing that water flows, regardless of urban areas or national borders, it is necessary to take care of the quality of river water. Although during the last 10 years, the ecological condition of the rivers was mostly improving, it has been determined that approximately $30 \%$ of all Lithuanian rivers do not comply with the good ecological condition requirements. One of the biggest sources of pollution is the agricultural pollution. Household wastewater introducing pollution to the river is also an important issue. The change in concentrations of these substances depends on the biochemical processes taking place in the water. Higher concentrations of nutrients can lead to eutrophication in slow-flow rivers, resulting in deterioration of ecological conditions in water bodies (Bukantis, 2008). There have been a number of studies that have considered assesment of ecological staus of surface water bodies (Kelly et al., 2009; Noges et al., 2009; Matysik et al., 2015; Cesoniene et al., 2017; Česonienė et al., 2019).

It was found that the majority of wastewater discharged Nemunas River basin. This basin receives untreated wastewater, wastewater from WWTP in urban, industrial and rural areas, waste from surface water treatment plants (Environment protection..., 2013). In order to reduce the impact of concentrated pollution on surface water bodies, Lithuania has been implementing the Directives of the European Council and other legal acts.

Water quality of the rivers cale can be affected by many natural and human factors. Water pollution sources are divided into diffused (nonpoint) and concentrated (point) sources according to the ways of their introduction to the river (Smol, 2008). Diffuse pollution in agriculture formed due to organic matter, nitrogen and phosphorus loads entering livestock manure and mineral fertilizers from fields and crops (Vaitiekūnienè, 2011). The household, industry and fisheries are the main sources of point pollution. Wastewater from these sources of pollution usually is treated and discharged into surface water bodies, mainly rivers, and contaminated by them (Šaulys, 2007; Ruminaité, 2010; Withers et al., 2011). The essential difference between them is that with the increase in distance from the local pollution source, one can detect an obvious reduction in environment pollution with the concentrated ones, and the diffused pollution sources include large territories and all of such territories are contaminated in a relatively uniform manner (Šveikauskaite, 2011).

The analysis of nutrient load from 23 wastewater treatment plants to the Berze River basin for the period 20052015 was performed. During this period average nitrogen and phosphorus load from WWTP to the river Berze basin have been reduced, but concentration of these biogenic substances in treated wastewater have increased (DambenieceMigliniece and Lagzdinš, 2017).

The effect of wastewater treatment plant on water quality of the Mažoji Sruoja River, Plunge district was analised during period of the year 2009-2014. Essential differences at $100 \mathrm{~m}$ distance above and $500 \mathrm{~m}$ below the wastewater

Copyright (c) 2019 The Authors. Published by Vytautas Magnus University. This is an open-access article distributed under the terms of the Creative Commons Attribution License (CC BY 4.0), which permits unrestricted use, distribution, and reproduction in any medium, provided the original author and source are credited. 
discharger of Plunge WWTP according to total phosphorus, total nitrogen and ammonia nitrogen were established in the water of the River Mažoji Sruoja. It was found that Plungė City wastewater had impact on the Mažoji Sruoja River water quality, and water quality of the Mažoji Sruoja River changed in different seasons of the year (Cesoniene et al., 2017).

Sources of diffuse pollution are present in the entire Šešupė basin. Arable land accounts for as much as 50 per cent of the total area of the basin, so the biogenic substances in the river water are increasing towards the downstreem. But there are also significant changes in the sources of point pollution in cities and settlements, as the Šešupe basin is densely populated (200 thousand inhabitants in the territory of Lithuania alone), and a quarter of them live in Marijampolé. Also, wastewater from Šakiai, Vilkaviškis, Lazdijai, Kalvarija and smaller towns reaches the Šešupe River (Šešupés..., 2014).

Municipal wastewater is a very composite mixture. Mainly it consists of such components as sewage from households, municipal establishments, and wastewater from industrial and commercial companies (Pescod, 1992). The industrial wastewater can be discharged to the sewerage systems or receivers after pretreatment. Small amounts of industrial wastewaters are discharged most often to urban sewerage system and are treated with municipal wastewater. There have been the studies that have considered the influence of waters resulted from the production of sugar from sugar beet on waters in wastewater treatment plants. The objective of the paper was to prove that wastes, especially organic ones, resulted from the production of sugar from sugar beet may have a significant effect on the quality of water entering or leaving wastewater treatment plants (Morar et al., 2016).

The aim of the paper was to determine the impact of Marijampole city wastewater treatment plant on the water quality of the Šešupe River.

\section{MATERIALS AND METHODS}

\section{Research area}

Šešupe is a $298 \mathrm{~km}$ long river, a tributary of the Nemunas River. It flows through the territory of Poland (27 km), Lithuania $(158 \mathrm{~km})$ and Russia $(62 \mathrm{~km})$. The Šešupe River has a contributing drainage area of $6104,8 \mathrm{~km}^{2}$. There are $80 \%$ of the Šešupe basin area and 53\% of the riverbed length in Lithuania. The biggest towns along the river, from the source to Nemunas River, are: Kalvarija, Marijampole and Kudirkos Naumiestis.

Water quality in the basin is affected by agricultural diffused pollution and variable point sources. The biggest concentrated pollution sources loading in the Šešupe River basin are wastewater treatment plants. The main concentrated pollution from Marijampolè, the largest city in the basin (load is equivalent to less than 100,000 PE), consists of the municipal wastewater and the production water of the seasonal work of sugar factory (UAB "Lietuvos cukrus"), which after the treatment enters the Šešupė River.

Design of the study

River water sampling places were selected considering comfortable and safe access during all seasons of the year. The first place was selected at the distance of $100 \mathrm{~m}$ above the discharger, where the treated Marijampolè wastewater has no impact on the river water quality. The second place was chosen where the wastewater is mixed with the river water at the distance of $500 \mathrm{~m}$ below the treatment plant discharger (Figure 1).
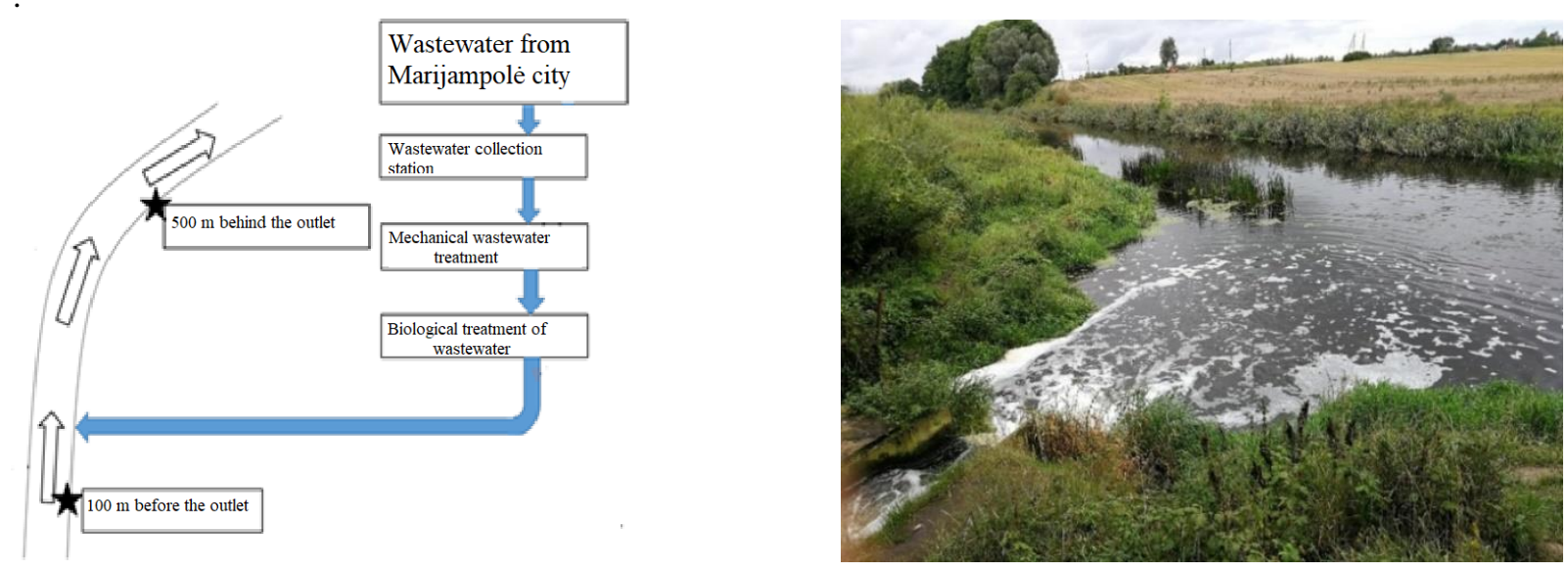

Figure 1. Marijampolè WWTP discharger

The water and wastewater samples were collected from January 2015 until December 2018. The ecological status of the surface water the Šešupe River is assessed 100 meters before and 500 meters after the release point. The analysis was carried out in the chemical analysis laboratory of JSC "Marijampolès vandenys" using special labour.

The pollution of wastewater has been assessed by identifying the $\mathrm{pH}, \mathrm{BOD}_{7}$ value and concentrations of total nitrogen (TN), total phosphorus (TP) and suspended materials.

The ecologic status of a river is assessed according to the following physical-chemical quality indicators: biochemical consumption of oxygen $\left(\mathrm{BOD}_{7}\right)$, nitrite nitrogen $\left(\mathrm{NO}_{2}-\mathrm{N}\right)$ ammonium ions nitrogen $\left(\mathrm{NH}_{4}-\mathrm{N}\right)$, nitrate nitrogen $\left(\mathrm{NO}_{3}-\mathrm{N}\right)$, total nitrogen $(\mathrm{TN})$, phosphate phosphorus $\left(\mathrm{PO}_{4}-\mathrm{P}\right)$, total phosphorus $(\mathrm{TP})$ and suspended solids. 
Was tested according to $\mathrm{BOD}_{7}$ - LST EN 1899-2:2000, suspended materials amount - LST EN 872-2005, TN LST EN 13342-2002 Determination of nitrogen - determination of bound nitrogen (TN), following oxidation to nitrogen oxides EN 12260:2003, $\mathrm{NO}_{3}-\mathrm{N}$ - LST ISO 9390:1998, NH4-N - LST ISO 7150-1:1998, $\mathrm{PO}_{4}-\mathrm{P}$ - LST EN ISO 6878:200, TP - LST EN ISO 15681-2:2019 Determination of orthophosphate and total phosphorus contents by flow analysis (FIA and CFA) - Part 2: Method by continuous flow analysis (CFA) (ISO 15681-2:2018) EN ISO 15681-2:2018.

The efficiency of wastewater treatment (\%) was calculated according to formula (1) (Wastewater Treatment Regulation, 2006):

$$
A E=\frac{M_{N V}-M_{V}}{M_{N V}} \times 100
$$

The linear trend and determination coefficient $\left(\mathrm{R}^{2}\right)$ were used to evaluate the dynamics of the wastewater cleaning efficiency (Microsoft Excel program).

For the differences between the wastewater cleaning efficiency has been used Student's criterion. The significance level of 0.05 was chosen (program STATISTICA).

\section{RESULTS}

Both Lithuanian and foreign authors point out that the status of river water is significantly influenced by point pollution as well as diffuse pollution. However, fluctuations in the concentration of nitrogen compounds are more influenced by the intensity of agricultural activity, while phosphorus compounds are more influenced by domestic sewage from settlements. These tendencies are explained by the fact that nitrogen is more easily leached from the soil due to its mobility properties. Meanwhile, phosphorus in the soil is usually in the form of coarse compounds, with high adsorption and plant uptake and limited release from the soil.

The average efficiency of wastewater treatment has been assessed by $\mathrm{BOD}_{7}, \mathrm{pH}$ value and concentrations of suspended materials, TN and TP. The wastewater treatment efficiency (\%) was calculated according to formula (1). The results are presented in Table 1.

Table 1. The average efficiency of wastewater treatment in Marijampolè city wastewater treatment plant (\%) in 2015-2018

\begin{tabular}{|l|l|l|l|l|}
\hline Data & Total phosphorus & Total nitrogen & BOD $_{7}$ & Suspended solids \\
\hline 2015 & 93 & 85 & 99 & 98 \\
\hline 2016 & 88 & 77 & 99 & 98 \\
\hline 2017 & 92 & 79 & 99 & 97 \\
\hline 2018 & 88 & 82 & 99 & 96 \\
\hline
\end{tabular}

The results show that the wastewater from JSC "Marijampolès vandenys" is treated efficiently, the efficiency of suspended solids is $96-98 \%, \mathrm{BOD}_{7}-99 \%, \mathrm{TN}-77-85 \%$, TP-88-93\%.

The determination coefficient and linear trend were used to evaluate the wastewater cleaning efficiency dynamics from January 2015 to December 2018. The results are presented in Fig. 2.

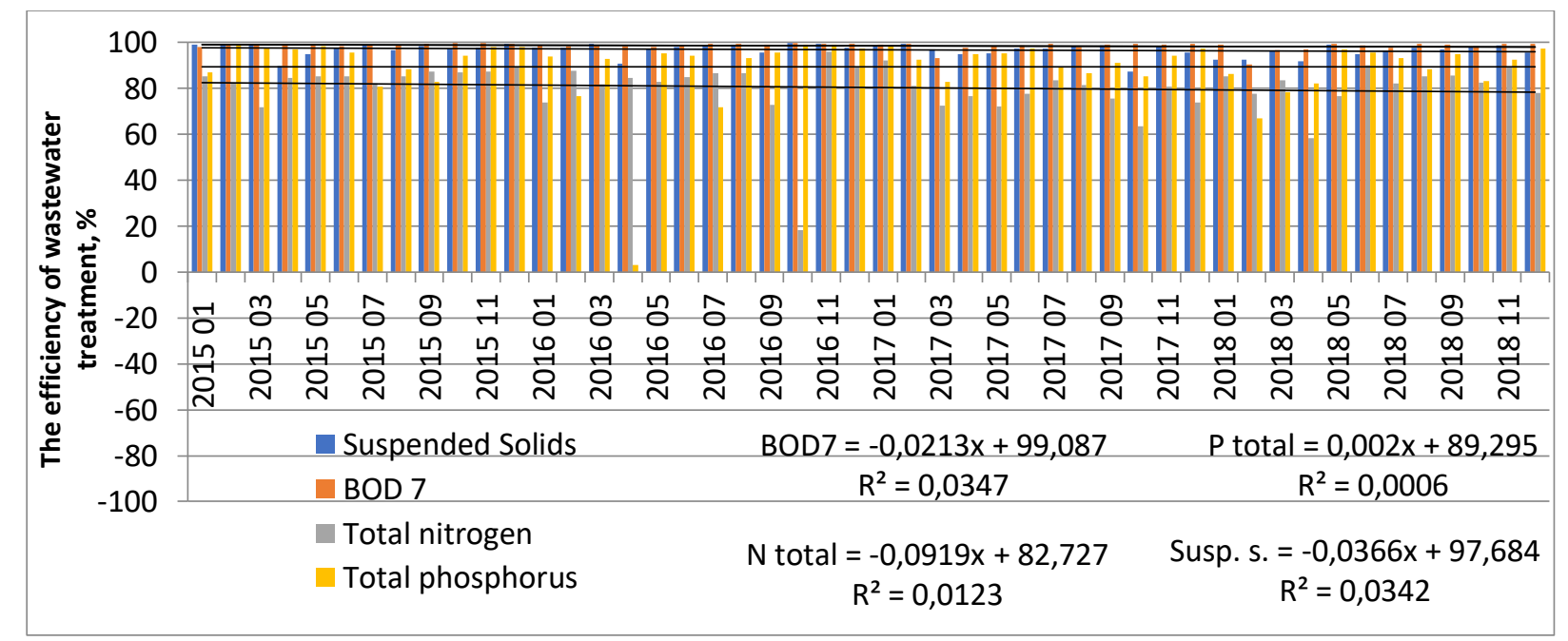

Figure 2. The efficiency of wastewater treatment in Marijampole city wastewater treatment plant of (\%)

The values all parameters of wastewater cleaning efficiency duration of the study were the same (the function is negative, and the determination coefficients are very low: $R^{2}=0.03 ; R^{2}=0.012 ; R^{2}=0.0006$; and $R^{2}=0.034$ ).

Cleaned wastewater from the Marijampole city wastewater treatment plant is flows into water Šešupe River. The average concentration of the $\mathrm{pH}$; suspended solids, $\mathrm{BOD}_{7}$ value, $\mathrm{NO}_{2}-\mathrm{N} ; \mathrm{NH}_{4}-\mathrm{H}, \mathrm{NO}_{3}-\mathrm{N}, \mathrm{PO}_{4}-\mathrm{P}$, total nitrogen, total phosphorus 
on the Šešupe River water is examined to evaluate the influence of the wastewater quality. The results are presented in Figure 3.

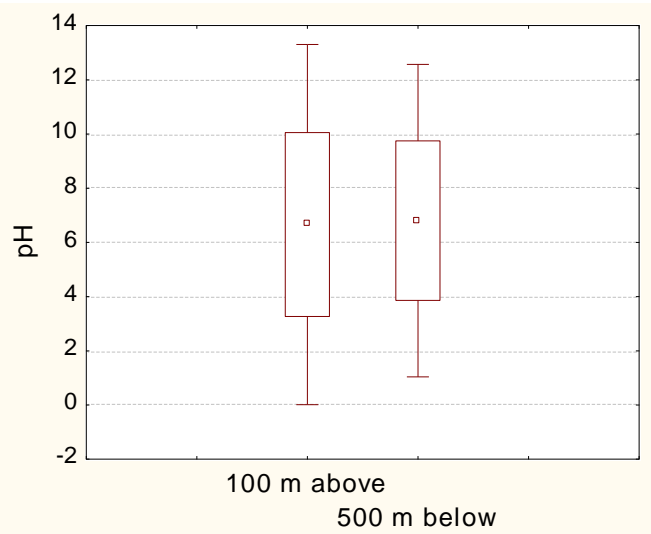

Outlet to the river Wastewater discharge

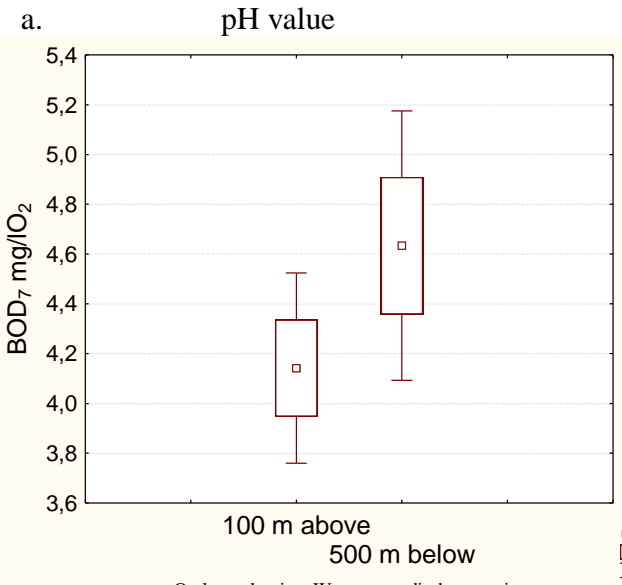

Outlet to the river Wastewater discharge point

c. $\quad \mathrm{BOD}_{7}$ value

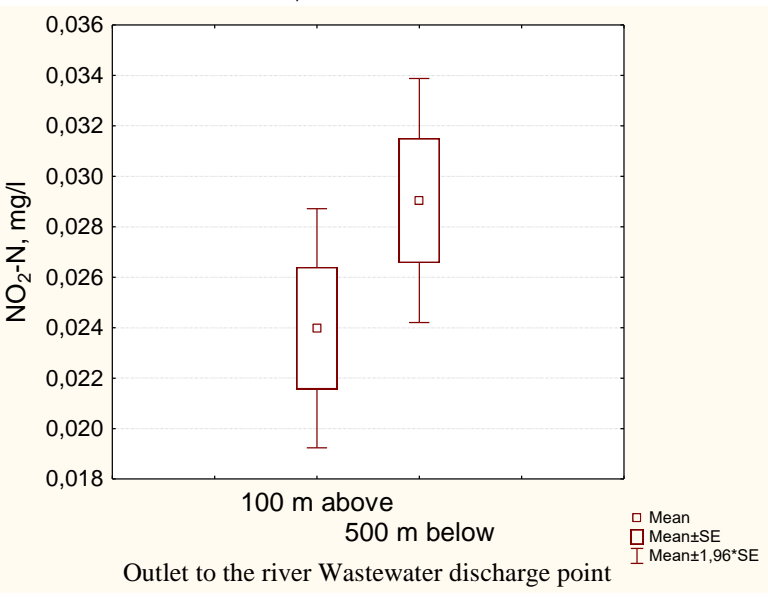

e. $\quad \mathrm{NO}_{2}-\mathrm{N}$ concentration

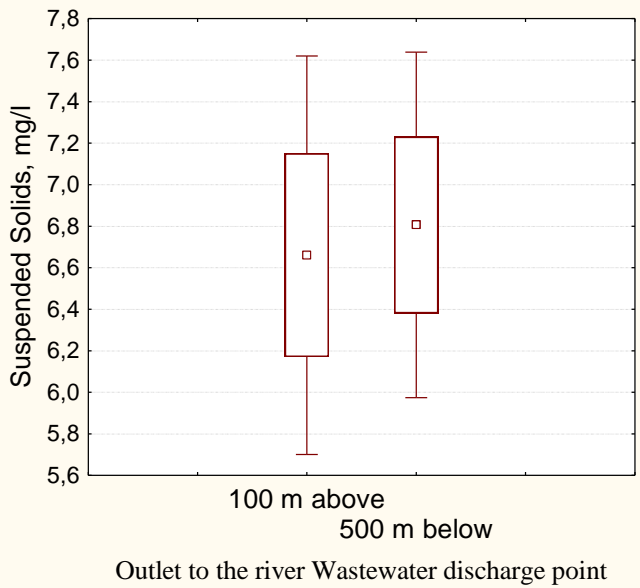

M Mean
$\square$ Mean \pm SE I Mean $\pm 1,96^{*} \mathrm{SE}$
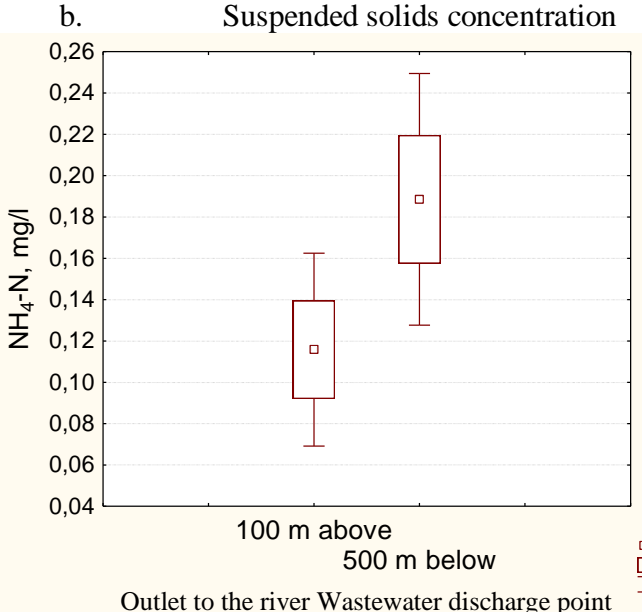

口 Mean I Mean $\pm 1,96 * \mathrm{SE}$

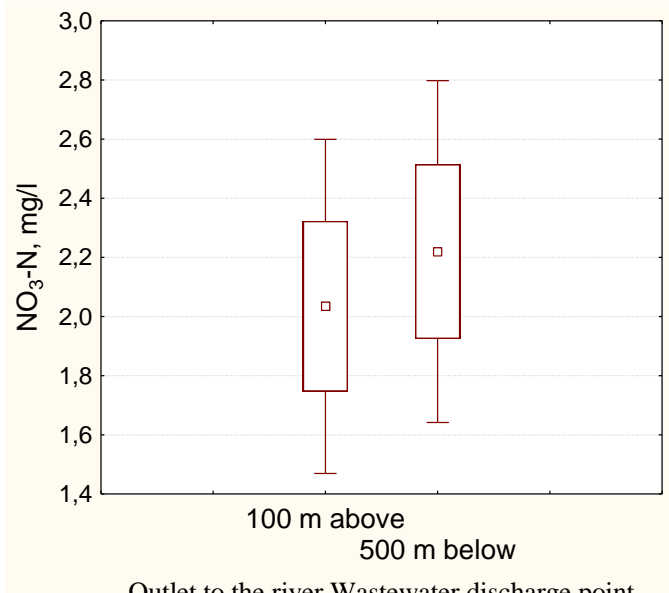

ㄴean MeantSE Outlet to the river Wastewater discharge point f. $\quad \mathrm{NO}_{3}-\mathrm{N}$ concentration 


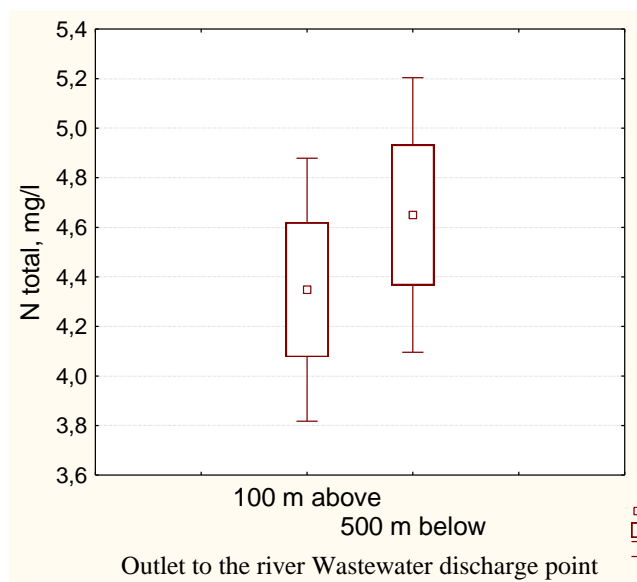

g. TN concentration

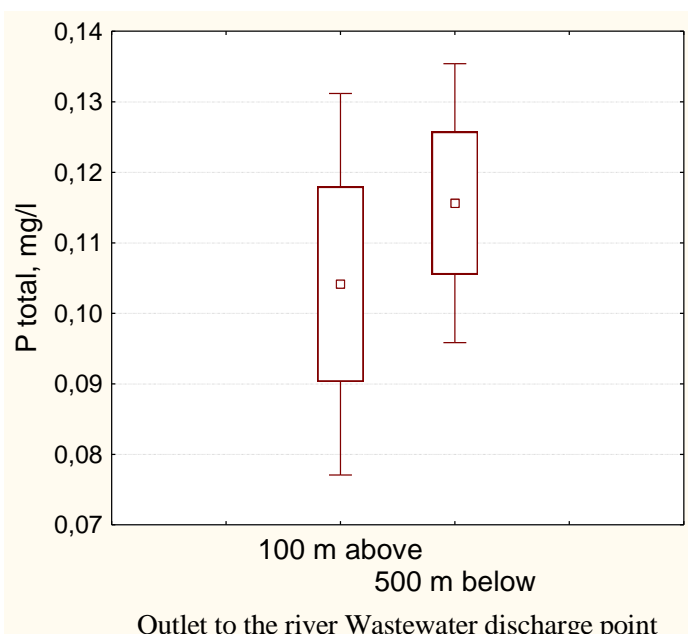

TP concentration

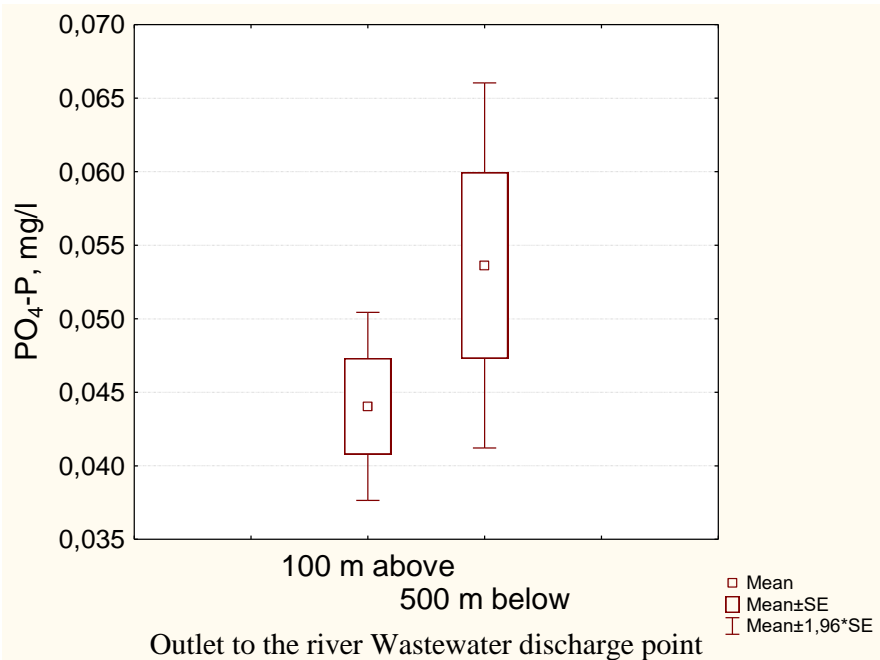

i. $\quad \mathrm{PO}_{4}-\mathrm{P}$ concentration

Figure 3. Chemical parameters in surface water: a.pH; b.Suspended solids; c. BOD7; d.NH4 $-\mathrm{H}$; e. $\mathrm{NO}_{2}-\mathrm{N}$; f.NO3-N; g.TN; h.TP, i.PO4-P

Concentrations of all indicators were found to be higher 500 meters below wastewater discharge point, the differences are statistically significant $(\mathrm{t}<0.05)$.

To evaluate the relation between the Šešupe River water quality values 500 meters below the wastewater discharge point and wastewater treatment efficiency, were calculated correlations. The results are presented in Table 2.

Table 2. The correlation of the Šešupe River's chemical water quality values (500 $\mathrm{m}$ after the wastewater discharge point) and the wastewater treatment efficiency

\begin{tabular}{|c|c|c|c|c|c|c|c|}
\hline $\begin{array}{l}\text { The efficiency of } \\
\text { wastewater treatment/ } \\
\text { Water quality values }\end{array}$ & $\begin{array}{c}\text { Suspended } \\
\text { solids, } \mathrm{mg} / \mathrm{l}\end{array}$ & $\begin{array}{l}\text { Ammonia } \\
\text { nitrogen, } \\
\mathrm{mg} / \mathrm{l}\end{array}$ & $\begin{array}{c}\text { Nitrites } \\
\text { nitrogen, } \\
\text { mg/l }\end{array}$ & $\begin{array}{c}\text { Nitrates } \\
\text { nitrogen, } \\
\mathrm{mg} / \mathrm{l}\end{array}$ & $\begin{array}{c}\text { Total } \\
\text { nitrogen, } \\
\mathrm{mg} / \mathrm{l}\end{array}$ & $\begin{array}{c}\text { Phosphates } \\
\text { phosphorus } \\
\mathrm{mg} / \mathrm{l}\end{array}$ & $\begin{array}{c}\text { Total } \\
\text { phosphorus } \\
\text {, mg/l }\end{array}$ \\
\hline Suspended Solids \% & $\begin{array}{c}r=-0.3625 \\
p=0.012\end{array}$ & $\begin{array}{c}\mathrm{r}=0.1213 \\
\mathrm{p}=0.417\end{array}$ & $\begin{array}{l}\mathrm{r}=-0.004 \\
\mathrm{p}=0.978\end{array}$ & $\begin{array}{l}\mathrm{r}=0.108 \\
\mathrm{p}=0.471\end{array}$ & $\begin{array}{c}r=-0.336 \\
p=0.049\end{array}$ & $\begin{array}{l}\mathrm{r}=0.0491 \\
\mathrm{p}=0.743\end{array}$ & $\begin{array}{c}\mathrm{r}=0.0431 \\
\mathrm{p}=0.774\end{array}$ \\
\hline $\mathrm{NH}_{4} \mathrm{~N}, \%$ & $\begin{array}{c}\mathrm{r}=-0.0613 \\
\mathrm{p}=0.682\end{array}$ & $\begin{array}{c}\mathrm{r}=0.0917 \\
\mathrm{p}=0.540\end{array}$ & $\begin{array}{l}\mathrm{r}=-0.021 \\
\mathrm{p}=0.887\end{array}$ & $\begin{array}{c}\mathrm{r}=0.1032 \\
\mathrm{p}=0.490\end{array}$ & $\begin{array}{l}\mathrm{r}=-0.042 \\
\mathrm{p}=0.779\end{array}$ & $\begin{array}{c}\mathrm{r}=-0.0408 \\
\mathrm{p}=0.785\end{array}$ & $\begin{array}{c}\mathrm{r}=-0.1106 \\
\mathrm{p}=0.459\end{array}$ \\
\hline $\mathrm{NO}_{2}-\mathrm{N} \%$ & $\begin{array}{c}\mathrm{r}=0.1545 \\
\mathrm{p}=0.300\end{array}$ & $\begin{array}{c}\mathrm{r}=0.1528 \\
\mathrm{p}=0.305\end{array}$ & $\begin{array}{c}\mathrm{r}=0.1485 \\
\mathrm{p}=0.319\end{array}$ & $\begin{array}{l}\mathrm{r}=0.191 \\
\mathrm{p}=0.196\end{array}$ & $\begin{array}{c}\mathrm{r}=-0.391 \\
\mathrm{p}=0.049\end{array}$ & $\begin{array}{c}\mathrm{r}=-0.1265 \\
\mathrm{p}=0.397\end{array}$ & $\begin{array}{c}\mathrm{r}=-0.0030 \\
\mathrm{p}=0.984\end{array}$ \\
\hline $\mathrm{NO}_{3}-\mathrm{N} \%$ & $\begin{array}{c}r=-0.0647 \\
p=0.666\end{array}$ & $\begin{array}{l}r=-0,089 \\
p=0.580\end{array}$ & $\begin{array}{c}\mathrm{r}=0.0188 \\
\mathrm{p}=0.900\end{array}$ & $\begin{array}{c}\mathrm{r}=0.0892 \\
\mathrm{p}=0.551\end{array}$ & $\begin{array}{c}r=0.1363 \\
p=0.361\end{array}$ & $\begin{array}{c}\mathrm{r}=0.0974 \\
\mathrm{p}=0.515\end{array}$ & $\begin{array}{c}\mathrm{r}=0.0595 \\
\mathrm{p}=0.691\end{array}$ \\
\hline $\mathrm{N} \%$ & $\begin{array}{c}\mathrm{r}=-\mathbf{0 . 4 2 9 6} \\
\mathrm{p}=\mathbf{0 . 0 2 1}\end{array}$ & $\begin{array}{c}\mathrm{r}=-\mathbf{0 . 4 7 9 8} \\
\mathrm{p}=0.047\end{array}$ & $\begin{array}{c}\mathrm{r}=0.1524 \\
\mathrm{p}=0.306\end{array}$ & $\begin{array}{c}\mathrm{r}=0.0980 \\
\mathrm{p}=0.512\end{array}$ & $\begin{array}{l}\mathrm{r}=0.1224 \\
\mathrm{p}=0.412\end{array}$ & $\begin{array}{c}\mathrm{r}=-0.0319 \\
\mathrm{p}=0.832\end{array}$ & $\begin{array}{c}r=0.0760 \\
p=0.612\end{array}$ \\
\hline $\mathrm{PO}_{4}-\mathrm{P} \%$ & $\begin{array}{c}\mathrm{r}=0.1283 \\
\mathrm{p}=0.390\end{array}$ & $\begin{array}{c}\mathrm{r}=-0.0019 \\
\mathrm{p}=0.990\end{array}$ & $\begin{array}{c}\mathrm{r}=0.1459 \\
\mathrm{p}=0.328\end{array}$ & $\begin{array}{l}\mathrm{r}=-0.44 \\
\mathrm{p}=0.048\end{array}$ & $\begin{array}{l}\mathrm{r}=-0.142 \\
\mathrm{p}=0.340\end{array}$ & $\begin{array}{c}\mathrm{r}=-0.1728 \\
\mathrm{p}=0.246\end{array}$ & $\begin{array}{l}r=-0.37 \\
p=0.046\end{array}$ \\
\hline $\mathrm{P} \%$ & $\begin{array}{c}\mathrm{r}=-0.0356 \\
\mathrm{p}=0.812\end{array}$ & $\begin{array}{l}\mathrm{r}=-0.183 \\
\mathrm{p}=0.218\end{array}$ & $\begin{array}{c}\mathrm{r}=0.0716 \\
\mathrm{p}=0.633\end{array}$ & $\begin{array}{c}\mathrm{r}=0.0541 \\
\mathrm{p}=0.718\end{array}$ & $\begin{array}{c}\mathrm{r}=0.1790 \\
\mathrm{p}=0.229\end{array}$ & $\begin{array}{c}\mathrm{r}=0.0109 \\
\mathrm{p}=0.942\end{array}$ & $\begin{array}{c}\mathrm{r}=-0.0442 \\
\mathrm{p}=0.768\end{array}$ \\
\hline
\end{tabular}


It was found that between the wastewater treatment efficiency for suspended solids $(\%)$ and the concentrations of total nitrogen and suspended solids, between the wastewater treatment efficiency for nitrites nitrogen $(\%)$ and the concentrations of total nitrogen, $\mathrm{NO}_{2}-\mathrm{N} \%$ and concentrations of the suspended solids and $\mathrm{NH}_{4}-\mathrm{N}$ mg/l; between PO4-P $\%$ and the concentrations of $\mathrm{P} \mathrm{mg} / \mathrm{l}$ and $\mathrm{NO}_{3}-\mathrm{N} \mathrm{mg} / \mathrm{l}$ in 500 meters below the wastewater discharge point in the Ššupe River - Significant negative correlation. It shows that the higher the treatment efficiency is, the better the quality of the surface water in the Šešupe River.

\section{CONCLUSIONS}

The results show that the wastewater treatment in Marijampole city WWTP is efficient. It has been determined that the values of all parameters of wastewater cleaning efficiency duration of the study was the same (the function is negative, and the determination coefficients are very low: $R^{2}=0.03 ; R^{2}=0.012 ; R^{2}=0.0006$ and $R^{2}=0.034$ ). The treated wastewater is released from the Marijampole WWTP into the Šešupe River. The highest concentration according to all examined parameters was in 500 meters below the flows of the wastewater. All differences were found to be statistically significant. It shows that, although wastewater is efficiently treated, it has a negative impact on the water quality of the Ššupe River.

\section{REFERENCES}

1. Bukantis A., Gedžiūnas P., Giedraitienė J., Ignatavičius G., Jonynas J., Kavaliauskas P., Lazauskienė J., Reipšleger R., Sakalauskienė G., Sinkevičius S., Šulijienė G., Žilinskas G., Valiukevičius G. Lietuvos gamtinè aplinka, būklè, procesai ir raida. Vilnius, 2008. 63 p. ISBN 978-9955-815-27-3

2. Cesoniene L., Dapkiene M., Sileikiene D., Rekašiene V. 2017. Impact of Wastewater Treatment Plant on Water Quality of the River Mazoji Sruoja, Plunge District. Journal of Environmental research, Engineering and Management, Vol. 73-3, pp. 33-44. https://doi.org/10.5755/j01.erem.73.3.16268

3. Česonienė, L., Sileikiene, D., Dapkiene, M., Radzevicius, A., Räsänen, K. 2019 Assessment of chemical and microbiological parameters on the Leite River Lithuania. Environmental Science and Pollution Research, Vol. 26, Iss. 18, pp $18752-18765$. https://doi.org/10.1007/s11356-019-04665-6

4. Kelly, M., Bennion H., Burgess A., Ellis J., Juggins S., Guthrie R., Jamieson J., Adriaenssens V., Yallop M. 2009. Uncertainty in ecological status assessments of lakes and rivers using diatoms. Hydrobiologia, Vol. 633, Iss. 1. pp 5-15 https://doi.org/10.1007/s10750-009-9872-Z

5. Matysik, M., Atsalon,D., Ruman, M. 2015. Surface Water Quality in Relation to Land Cover in Agricultural Catchments (Liswarta River Basin Case Study). Polish Journal of Environmental Studies, Vol. 24 (1), pp. 175-184. https://doi.org/10.15244/pjoes/26203

6. Ministry of Environment of the Republic of Lithuania. Description of procedure of surface water ecological status assessment. Žinios, 2011, Nr. 109-5146. (in Lithuanian).

7. Morar, F., Rus, D., Lung, B. I. 2016. The Influence of Sugar-Processing Effects on Water in Treatment Plants. Procedia Technology, Vol. 22, pp. 486-492 https://doi.org/10.1016/j.protcy.2016.01.098.

8. Nõges P., Van de Bund W., Cardoso A.K., Solimini A.G., Heiskanen A.S. 2009 Assessment of the ecological status of European surface waters: a work in progress. Hydrobiologia, Vol. 633 (1), pp. 197-211. https://doi.org/10.1007/s10750-009-9883-9

9. Smol J.P. 2008. Pollution of lakes and rivers: a paleoenvironmental perspectives. Blackwell Publishing, Hoboken. Šešupès baseino ir jos intakų baseinų upès, 2014, [interactive] http://www.upese.lt/index.php/upes-pagal-baseinus/sesupes-baseinas. (In Lithuanian).

10. Šveikauskaitė I. 2011. Lietuvos upių teršimas bei vandens kokybès kitimo tendencijos 1992 - 2009 m. (Master thesis) (in Lithuanian).

11. Environmental Protection Agency. 2013. Review of the protection problems of surface water bodies in the Nemunas river basin districts [interactive]/Aplinkos apsaugos agentūra. Nemuno upių baseinų rajonų paviršinių vandens telkinių apsaugos problemų apžvalga [interaktyvus]. Environmental Protection Agency.

12. Dambeniece-Migliniece, L., Lagzdiņš, A. 2017. Impacts of municipal wastewater treatment plants on water quality in the Berze river basin. Research for Rural Development, pp. 153-159. https://doi.org/10.22616/rrd.23.2017.022

13. Pescod, M.B. 1992. Wastewater treatment and use in agriculture. M.B. Pescod, Ed. Rome: Food and Agriculture Organization of the United Nations.

14. Ruminaite, R. 2010. Water runoff and pollution peculiarities in Lielupe watershed per 1992-2006 year period. Water Management Engineering, Vol. 36(56), pp 100-108 (in Lithuanian).

15. Šaulys, V. 2007. Vandenų apsaugos politika ir teisè, Mokomoji knyga, Vilnius, (in Lithuanian). https://doi.org/10.3846/944-S

16. Wastewater Treatment Regulation/ Nuotekų tvarkymo reglamentas, 2008. [interaktyvus]/Order of the Minister of the Environment of the Republic of Lithuania: 17 May 2006. No. D1-236. [interactive]. https://eseimas.lrs.lt/portal/legalAct/lt/TAD/TAIS.276576/bJLwtUrcMj. Accessed 30 Jan 2019.

17. Withers, P.J., Jarvie, H.P., Hodgkinson, R., Palmer-Felgate, E.J., Bates, A., Neal, M., Wickham, H.D. 2011. Characterization of phosphorus sources in rural watersheds. Journal of Environmental Quality, Vol. 38(5), pp. $1998-2011$. $\underline{\text { https://doi.org/10.2134/jeq2008.0096 }}$ 